\title{
MILITANT CATHOLICISM, INTER-CONFESSIONAL RELATIONS, AND THE ROOKWOOD FAMILY OF STANNINGFIELD, SUFFOLK, c. 1689-1737*
}

\author{
CARYS BROWN \\ St John's College, Cambridge
}

\begin{abstract}
Explanations of local interconfessional relations in post-revolutionary England tend to highlight the role of Catholic quiescence and compromise in allowing Protestants and Catholics to "get along”. By examining the interactions of a Catholic family who were far from quiescent in their religious and political practice, this article suggests that these explanations may overemphasize the compromise of religious minorities, obscuring the importance of the wider local context to the shape of interconfessional relations. The subjects of this study, the Rookwoods of Stanningfield, Suffolk, were active in expression of Catholic religion and its political implications. Contrary to patterns suggested elsewhere, the social and economic interactions of this family with their neighbours illustrate that such ardent Catholicism was not enough to prevent cordial relations with local Protestants. The social and economic importance of the Rookwoods within their community is used to make suggestions as to why they were accepted on the local level against a backdrop of wider anti-Catholic polemic. The example of the Rookwoods implies a need to explore the broader factors which shaped the underlying balance of power on a local level before it is possible to understand the nature of compromises that allowed for peaceful coexistence.
\end{abstract}

'Wee the Neighbours and Acquaintances of Thomas Rookwood...Doe most humbly certify \& declare That he did for severall yeares live \& reside amongst us, in the time of his late Majesties Reigne: Dureing all which time...hee demeaned himselfe inoffensively, and with respect to the Lawes. And wee are strongly induced to believe, That hee would still constantly manifest a due Observance of them, and a just and dutifull regard and obedience to your Majesties Government...And for his quiet and peaceable behaviour towards your Majesties Royall person and Government, Wee presume...That wee may be 
his guarantees.'1

In 1702, eleven Protestant men petitioned Queen Anne to allow the return from exile of Thomas Rookwood, their Catholic neighbour, to his home in Stanningfield, Suffolk. By his neighbours' account, Thomas Rookwood was a law-abiding man who posed no threat to the peace. Evidence of the Rookwood family's conduct suggests that this was not strictly true. Thomas's brother, Ambrose, had been tried and executed for involvement in an assassination attempt on William III in 1696, and another brother, Henry, was a Catholic priest. Thomas had shown his own Jacobite colours by refusing to sign the Association Oath in 1696. In addition the Rookwood family home, containing numerous Catholic icons, stood as an imposing reminder to the Catholic presence of the family in the locality. In this, the Rookwoods fitted anti-Catholic stereotypes well. Yet Thomas's relationship with his Protestant neighbours was amicable enough not only for his neighbours to beg for his return from exile, but also for them to dine and hunt with him. This article explores the reasons for friendly inter-confessional relations in the face of militant Catholicism in Stanningfield, and suggests the broader implications of this case for understandings of the interactions between religious ideology and economic and social imperatives on a local level.

Peaceful confessional coexistence was not simply an expression of tolerance in this period. Far from acting as polar opposites, tolerance and intolerance persisted alongside and fed into each other. $^{2}$ This complexity is demonstrated in studies of confessional coexistence on a local level. In the Dutch Republic, for instance, Willem Frijhoff concluded that everyday coexistence 'involved a muddled toleration...which we call the ecumenicism of everyday relations'. Toleration was not so much an ideological stance as the outcome of everyday necessity. ${ }^{3}$ Benjamin Kaplan has demonstrated the relevance of this elsewhere in Europe, where communities relied on elaborate pragmatic arrangements in order to cope with tensions and overlaps between religious, political, and social life. ${ }^{4}$ So misleading has the ideologically loaded term "toleration" proved that William Sheils has argued that it is better replaced by the language of 'getting along' and 'getting on', which describe the everyday negotiations which allowed Catholics and Protestants to live together. ${ }^{5}$ 
Similarly, Nadine Lewycky and Adam Morton write of 'neighbourliness' between confessions, describing it as less a rejection of intolerance, than 'a negotiation of its practical limitations'. ${ }^{6}$ Confessional coexistence, by all accounts, relied on complex practical arrangements on a local level.

The extent of the ideological and practical effects of arrangements for coexistence between English Protestants and Catholics during this period remains a matter of extensive debate. Colin Haydon has shown the strength of anti-Catholicism throughout much of the eighteenth century as a crucial mode of Protestant social bonding and identity formation. ${ }^{7}$ There may, however, have been a disjuncture between angst about the abstract Catholic and the behaviour of individuals when met with real Catholic neighbours. ${ }^{8}$ As Gregory Hanlon's work on relations between Catholics and Protestants in Aquitaine reminds us, the possibility of a rupture between discourse and behaviour demands consideration. ${ }^{9}$ This is reflected in studies of English Catholics in local communities in this period, which have shown the extent to which Catholics and Protestants lived alongside each other in a peaceable manner for the sake of community functions. In Madeley, Shropshire, for instance, Catholics were well integrated, even occasionally serving as churchwardens. ${ }^{10}$ 'Getting along' with Catholics was vital for everyday Protestant life in English communities. ${ }^{11}$ This degree of integration sits uncomfortably with anti-Catholic discourses in this period.

This contradiction has been explained in several ways. Firstly, it is suggested that Catholics were politically inactive and submissive to the Protestant community during the post-revolutionary period, and this facilitated acceptance by confessionally different neighbours. John Bossy states that 'the consensus of Catholics between (at least) 1715 and 1760 was that politics was in general a danger to the soul and in particular none of their business. ${ }^{12}$ If Catholics no longer represented a political threat, Protestants were more likely to accommodate them. Sheils's work backs up this view, finding a 'withdrawal by the Catholics from the wider community in response to a more assertive local Protestant presence' in Egton between 1680 and 1780, and emphasizing that 'accommodation and compromise were as important as firm conviction to the Catholics at Egton'. ${ }^{13}$ Lewycky and Morton have built upon and challenged these 
conclusions, stressing the difficulty of juggling kinship, family, fraternity, and religion for all denominations. For both Catholic and Protestant, 'life was a series of moral dilemmas'. ${ }^{14}$ In this view, local relations between Protestants and Catholics from the late seventeenth century onwards were based on constant compromise. This can explain for some contexts why anti-Catholicism, still strong in the general sense, was not applied to individual Catholics with whom Protestants interacted. The stereotype of the 'Bloody Papist' was suspended by Protestants with reference to well-known local individuals, who were believed to be atypical of the whole. ${ }^{15}$ Benjamin Kaplan has framed this in terms of a difference between individual and group cohesion, suggesting that individuals could be mixed whilst their religious groupings rejected one another as a whole. ${ }^{16}$ These explanations of neighbourly relations suggests that the cooperative and non-threatening Catholics encountered by Protestants on a local level were treated as special exceptions to general understandings of Catholics.

The emphasis on pragmatism and compromise evident in these explanations fails to account for instances where religious minorities were far from compromising in their religious and political behaviour, and yet remained integrated within their local communities. Adding to a recent recognition of the resilience and political engagement of Catholics after $1688,{ }^{17}$ this article suggests that there has been an historiographical overemphasis on the centrality of the compromise and quiescence of Catholics to securing peaceable interconfessional relations. The case study used here looks at how confessional coexistence was able to operate when Protestants were faced with uncompromising individuals who matched anti-Catholic stereotypes. Analysis of the nature of the relationship between Protestants and Catholics in this instance suggests the importance of local conditions to the balance of power in interconfessional relationships. The onus for compromise was not always where we might expect; the established majority did not necessarily have the last word.

The Rookwood family of Stanningfield, Suffolk, provides an ideal case study through which to examine interconfessional relations in local context. Established in the local area since at least the fourteenth century, they had achieved notoriety on more than one occasion for their actions in the name of their religion. ${ }^{18}$ Despite the recusancy fines and danger of crown 
confiscation presented by the involvement of two of the family in treasonous plots in 1605 and 1696, however, Coldham Hall and the surrounding family estate remained more or less intact, making the Rookwoods substantial landowners. ${ }^{19}$ By 1722-3 lands held by Thomas Rookwood fetched a rental income of $£ 52210$ s per annum, covering much of the area between Hawsted, Lawshall, and Stanningfield. ${ }^{20}$ The physical presence of the family was also evident in Stanningfield Parish Church, which still contains an impressive chancel built by a Thomas Rookwood in the fourteenth century as well as monuments to and graves of the family, including the grave of another Thomas Rookwood, the main subject of this study, who died in 1726 and was buried near the altar. ${ }^{21}$ Whilst Catholic and Protestant canonical guidance on the burial of Catholics within Protestant churches was ambiguous, it was common for wealthy Catholics to assert their social influence to secure the display of their power and prestige at the heart of their community. ${ }^{22}$ This was undoubtedly the case for the Rookwoods in Stanningfield.

Assertion of social influence did not, however, appear to interfere with the family's Catholicism. Beyond Suffolk the family were well integrated through marriage within a Catholic gentry network. Rookwoods were married to the Drury, Townsend, Caldwell, Martin, and Gage families, all Catholic families of some stature. ${ }^{23}$ The children of these marriages were educated at Catholic colleges and convent schools on the continent, and a substantial proportion of the family became priests and nuns. ${ }^{24}$ The broad spectrum of Catholic gentry life within the family makes the Rookwoods illuminating subjects for study, as does the nature of the source material available. Whilst direct commentary on the family's religious practices is scarce, several sources provide a valuable insight into the interactions of the family with their neighbours as well as accounts of the difficulties they faced as a result of their more seditious activities. The ledger of Thomas Rookwood, begun in around 1696 and continued by his daughter, Elizabeth, after his death, is particularly valuable for understanding the nature of their relationships with members of their locality. It also details the way the estate's money was used to support the family's Catholicism. ${ }^{25}$ The letter to Queen Anne quoted at the beginning of this article is also among the family papers, 
and opens up one of the more difficult episodes in Thomas Rookwood's life. This is supplemented by appearances of the family in the state papers, parliamentary lists of papists, court of chancery records, and references to the family in the records at Suffolk record office in Bury St. Edmunds and in the archives of the English Province of the Society of Jesus, which contribute to a more rounded picture of the family. Drawing on these diverse sources, I begin by examining the religious and political activity of the Rookwoods. ${ }^{26}$ This is followed by an analysis of the nature of the relationship between the family and their neighbours. I conclude with an explanation for the nature of this relationship, emphasizing that it was not so much the quiescence of Catholics that was key to their 'getting along' with Protestant neighbours, but rather that religious concerns were sometimes mediated through economic necessity and local structures of sociability and neighbourliness in a way that encouraged peaceful co-existence in this locality. Religion, politics, economy, and society are treated here as inextricably intertwined; if they appear on occasion to be analysed as separate entities it is a matter of heuristic necessity rather than rigid categorisation.

As Haydon's work has shown, few contemporary anti-Catholic writers would have agreed with the idea of the quiescent Catholic predominant in the historiography. ${ }^{27}$ Protestant pamphleteers described Catholicism as a corruption of Christianity, controlled by the Anti-Christ through the Pope, who encouraged superstition and idol worship. ${ }^{28}$ Thus, wrote the Weekly Observator in June 1716, 'A Papist is an Idolator, who worships Images, Pictures, Stocks and Stones...prefers Traditions before the Holy Scriptures... [and deems] it meritorious to kill a Heritick'. ${ }^{29}$ Even aside from their bloody-thirstiness, Catholics were seen as irreligious fools, as conveyed by the prolific satirist and loyalist tory propagandist Jonathan Swift in the 'Popish Courant' of 1714, which included amongst the Pope's 'standing 
troops...many Legions of Fanatical Voteries; the Ignorant, the Malancholy, the Malecontented, the Jealous, the Disappointed, the Bankrupt, the Superstitious, $\& c^{\prime} .{ }^{30}$ For these authors, Catholics were the embodiment of irreligion. This was a message applied with particular vehemence to descriptions of Catholic clerics, who were feared to be tricking individuals into converting to Catholicism. The notion that the entire Catholic faith was built upon duplicity was a strong theme; priests were described as refusing to allow their followers to see the clear light of the gospel through access to God's word. ${ }^{31}$ The idea that Catholics were religiously suspect, morally defunct, and politically dangerous was widespread, reinforced through church liturgy and sermons, popular commemorations, and the increasingly wide circulation of print $^{32}$

Had the authors of anti-Catholic tracts entered Coldham Hall, they might have felt somewhat vindicated. The building contained a large number of religious images, artefacts, and a significant collection of devotional and polemical books. The Coldham Inventory, which begins with a survey of household effects in 1737, makes clear the extent to which the family's ardent Catholicism was plastered across the inside of the house. As well as numerous devotional pictures, including 'Two pictures of our Saviour \& Lady on wood...A picture of the pope...On the Stair Case one picture of St Ignatius', there was to be found on the stair case 'one picture of Mrs Cary a nun full length'. ${ }^{33}$ Such pictures, especially a lifesized picture of a nun, can hardly have failed to be provocative to Protestants, who, as we shall see, did visit Coldham Hall. Religious imagery remained controversial in this period. As Clare Haynes has demonstrated in her study of dispute over a statue in All Hallows', Barking, in 1681, it was an issue which 'reached to the heart of what identified the Church of England as a reformed and "true" church'. Religious images could be taken as symbols which highlighted the contested nature of the Church of England, and their predominance within a Catholic context could provide a physical confirmation of the notion that Catholics were idolaters. ${ }^{34}$ The images hanging around Coldham Hall suggest that the Rookwoods, at least within their home, made no attempt to hide their Catholicism. The list of nearly 2000 books held in the family's library also indicates their continuing religious engagement. ${ }^{35}$ The family owned c. 700 books on religious matters or church history, amongst which were Catholic devotional texts 
such as John Gother's Instructions for Mass and Confession as well as the more controversial works of Thomas Tylden (alias Godden), John Sargeant, and Serenus Cressy. ${ }^{36}$ Whilst no commonplace book exists for the Rookwoods to give indication of who read these books or how they used them, the collection provides a further reminder of the material presence of Catholicism in the fabric of the family's home. ${ }^{37}$ Within the "private" devotional context of their household, the Rookwoods were uncompromising in their religion. ${ }^{38}$

The Rookwoods did not confine their religious activity to Coldham Hall. Rather, they acted out the desire to sustain their religion through the methods most feared by Protestants. The image of the 'Popish Priest' as a devious criminal and seducer of the foolish was at the centre of anti-Catholic discourse. This was particularly the case for Jesuits, who, as the most actively proselytizing of Catholic orders, were often the subjects of abuse and suspicion in contemporary polemic. There were both priests and Jesuits in the Rookwood family. Thomas's brother, Henry Rookwood, S. J., served Coldham Hall as a priest from 1691 onwards, and was supported in this role by an annuity from the Coldham estate, alongside payments from the College of Holy Apostles. ${ }^{39}$ The Rookwoods had maintained a Catholic chapel since the sixteenth century, ${ }^{40}$ and it is likely that this would have been commonly known in the area, particularly given the arrest of Fr Thomas Garnet on his way to Coldham Hall in 1605 and his subsequent execution at Tyburn in $1608 .^{41}$ The presence of a Rookwood family member as priest to Coldham therefore hardly represents the 'accommodation and compromise' in conviction painted as important in relations between Catholics and Protestants during this period. ${ }^{42}$ Henry's role as priest to the Coldham mission would have appeared particularly suspicious in the light of previous seditious activity surrounding the family. Whilst Fr Garnet's arrest may have been out of living memory, other suspicious religious activities could be remembered. Episcopal returns for 1669, for instance, report a Papist Conventicle in Stanningfield at 'Sr Robt Crookefields', almost certainly referring to Sir Robert Rookwood, the sort of secret activity which would have caused significant alarm. ${ }^{43}$

Furthermore, the Rookwoods' involvement in the continuing survival of Catholicism in England extended beyond priesthood. The family were undeniably active participants in a Catholic network. From 
Coldham Hall, Thomas Rookwood and his daughter exploited a chain of local connections that enabled them to ensure the financial welfare of their relations who were serving the Catholic cause further afield. This included Francis Rookwood, O.S.B., John Rookwood, O.S.F., Henry Rookwood, S.J., and a number of Thomas's sisters, who were Poor Clares at Dunkirk. ${ }^{44}$ All were sent money through inventive methods when they were not at Coldham to receive it themselves. ${ }^{45}$ Elizabeth Rookwood's ledger entry for 30 May 1730 states 'this day payd \& returnd my Unkle Franck Rookwood his Annuity...returned it by Mr Browne groser of bury in the hands of Mr Kerwood a surgeon in great queen street to be given to Mr Phillips att the golden Cup Convernt garden'. ${ }^{46}$ This convoluted route was used repeatedly, alongside money given to 'Mr Rocby for my Aunts att dunkerk', ${ }^{47}$ and represented a particularly calculated attempt at subversion. The use of such connections to reach members of the family appears to have been common practice for Thomas Rookwood during his life-time, and implies a determination to ensure the continued survival of the Catholic religion, even at the family's own risk. The wider entrenchment of the family within a Catholic community outside of Stanningfield would be expected to count against them when it came to community relations in a period when Catholics alien to a locality were viewed with particular suspicion. Perhaps even more threatening to the local community and the state were the strong connections of the Rookwoods to the continent. Of the daughters of Ambrose Rookwood and Elizabeth Caldwell (Thomas's parents), Anna, Mary, Frances and Clare followed in their aunts' (Frances and Mary) footsteps and became Poor Clares at Dunkirk, whilst their sister, also called Frances, became an Augustinian at Bruges. ${ }^{48}$ Both were institutions with the ultimate aim of restoring Catholicism to dominance in England. Obvious involvement at the centre of the Catholic mission made the Rookwoods more dangerous in their religion in the eyes of contemporaries. The state recognised the role of the religious seminaries abroad in perpetuating Catholicism, with the 'Act for Further Preventing the Growth of Popery' of 1700 rewarding informants who reported on the dispatch of children overseas for the purpose of a Catholic education. ${ }^{49}$ Furthermore, as the work of Claire Walker has demonstrated, nuns were often heavily involved in the Catholic mission outside of the nunneries in their attempts to create a situation in which they could bring their cloisters home. ${ }^{50}$ The foundation and continuing existence of convents was itself a political act, 
designed to secure the future return of England to Roman Catholicism, one which was undertaken by a majority of the female members of the Rookwood family. ${ }^{51}$

We should not assume that the Rookwood family's Protestant neighbours would have been fully aware of the above. Nevertheless, it is clear that this was not a family who made an effort to confine their Catholicism to private practice. In their religious behaviour the Rookwoods were far from compromising or retiring in the face of the Protestant majority. Rather, they kept within the walls of Coldham an indisputably Catholic space. Furthermore, outside the walls of their home they used the fruits of their estate to support members of their family who were actively involved in the Catholic mission. ${ }^{52}$ The Catholicism of the Rookwoods was ardent and potentially threatening, making it all the more surprising that Thomas Rookwood's neighbours ascribed to him an obedient and inoffensive nature.

\section{II}

The family's religious practice was not the only indication that they were far from quiet and obedient subjects. Anti-Catholicism stretched to political discourse in this period, and the Rookwoods' behaviour could be considered highly inflammatory in this regard. Memory of Catholic action across the seventeenth century, including the Gunpowder Plot of 1605 (commemorated yearly in Fifth of November parades and pope burnings) and the attempts of James II to pack parliament in 1687, allowed Protestant writers to portray Catholics as disloyal absolutists. ${ }^{53}$ One sermon published in support of the Glorious Revolution by Gilbert Burnet, Bishop of Salisbury, in 1713, made a the case that Catholicism arose from self-interest, accusing Catholic leaders 'of raising their own authority' and 'of Wealth and Ease' at the expense of others. ${ }^{54}$ Burnet, as a Williamite minister who had been out of favour under James II, would have been expected to hold this position. ${ }^{55} \mathrm{He}$ was, however, far from isolated in his opinion. William Crookshank, minister of the Scots Church in Westminster, reminded his congregation in a sermon responding to the Jacobite Rising in 1745 that it was 'incumbent upon all Protestants, to have an utter 
Aversion to Popery, which breathes forth nothing but Cruelty, Devastation, and Blood ${ }^{56}$ Whig publications in particular espoused anti-Catholic ideologies as a way of highlighting their own superiority in opposition to superstitious popery. The Occasional paper and the Old whig, both periodicals with a dissenting whig connection, made a strong contrast between Protestants and "Papists" a frequent theme of their issues, bringing together religious criticism with an emphasis on political danger. ${ }^{57}$

To some extent this view of Catholics as a political threat was justified. Genuine Jacobite plots and rebellions in 1696, 1715, 1722, and 1745 were periodic reminders that many Catholics wanted to restore James II and his descendants to the throne. ${ }^{58}$ Furthermore, expression of this desire was not confined to flashpoints of violent action. Between 1714 and 1724 no other group in opposition to the reigning Whigs was able to rival the scale of Jacobite print production. ${ }^{59}$ This was complemented by a proliferation of Jacobite material culture, including coins, earthenware, prints, textiles, and glassware displaying Jacobite motifs. ${ }^{60}$ The proliferation of print and material objects associated with Jacobitism was a reflection of a wider Jacobite society, in which Jacobites were social as well as political associates. ${ }^{61}$ Whilst there were Protestant members of this milieu, the notion that it was dominated by Catholics was more than a myth created by Walpole's government. In particular, as Glickman has shown, Jacobite politics thrived in the English colleges on the continent, whilst clerical Jacobitism meant that loyalty to the Stuarts was encouraged by priests in England. ${ }^{62}$

Fear of Jacobites manifested itself in real action at state level, with Robert Walpole using it to shore up his position in office. ${ }^{63}$ This was aided by George I and George II who proscribed the tories from office partly for their Jacobite connections. ${ }^{64}$ Walpole was able to force a new $£ 100,000$ levy on English Catholic land through parliament in 1722 in addition to the double land tax already imposed on Catholic estates, despite objections from a number of Protestants and outcries from the Catholic community. ${ }^{65}$ This happened against a background of laws already in place that perpetuated the idea that Catholics were untrustworthy. This was clear from the wording of a 1678 act disabling Catholics from sitting in parliament, which suggested that the measure was necessary to protect the 'Safety of His Majestyes Royall Person and Government' from ‘the Increase and Danger of Popery' ${ }^{66}$ The 'Act of Toleration' of 
1689 had brought about limited toleration for dissenting Protestants, but Catholics were excluded entirely. ${ }^{67}$ As a result of this, Catholics theoretically still faced severe legal restrictions, including fines for recusancy, exclusion from parliament, and periodic requirements to take oaths of loyalty and register their estates. ${ }^{68}$ A new act in 1697 in response to the 1696 Jacobite assassination attempt made it very difficult for Catholics who were abroad to return home to England. Furthermore, in 1698 another act ensured that Catholics would not be able to inherit land unless they took the Oath of Allegiance. ${ }^{69}$ In sermon, print, and statute, Catholics were untrustworthy and unsuitable for office.

The actions of the Rookwoods matched this stereotype of Catholics in almost every respect. Ambrose Rookwood (the younger) was involved at the centre of the very high profile plot to assassinate William III in 1696 that had prompted the instigation of the aforementioned Oath of Allegiance and the Act of Banishment which forced Thomas Rookwood into exile. Papers concerning Ambrose's trial for treason and subsequent execution were published, emphasising the actions of Ambrose and the other conspirators as being 'most impious, wicked, and devilish Treasons, and Traiterous compassings, contrivances, and purposes' ${ }^{70}$ whilst God's intervention in preventing the plot was celebrated. ${ }^{71}$ The enduring memory of the plot was demonstrated by the publication in 1723 of Sir Richard Blackmore's officially commissioned history of the conspiracy. ${ }^{72}$ The fact that a member of the Rookwood family had been involved in this Jacobite plot was unlikely to have been forgotten, particularly given the execution of his great-grandfather (another Ambrose) in 1606 for involvement in the Gunpowder Plot. Furthermore, the Rookwoods' Jacobitism was demonstrated locally in 1696, when Thomas Rookwood refused to declare his loyalty to King William III in the Association Oath. ${ }^{73}$ Following Ambrose Rookwood's involvement in the plot to assassinate the King, such refusal would have appeared extremely suspicious. Thomas absented himself from the community in exile for a number of years after this, and suspicion can surely only have been heightened by periods spent abroad in the early $1690 \mathrm{~s}^{74}$ This makes all the more significant his neighbours' support for his return in their letter to Queen Anne in 1702. Furthermore, Thomas did not relent in his disobedience upon his return home. Although there is no evidence of any involvement by the family in the 1715 Jacobite rebellion, Thomas is recorded as having refused the 
Hanoverian oath of allegiance instigated after the Atterbury Plot of $1722 .^{75}$ The Rookwood family undeniably had a treasonous past and present which was widely known. By treating a local Catholic from a suspect family in a friendly manner, local Protestants were going against the view encouraged by the government of all Catholics as dangers to Church and State.

The Rookwood family did not confine their political activities to Jacobitism. They were also engaged in local political wrangling, challenging suggestions that Catholics thought that 'politics was in general a danger to the soul and in particular none of their business'. ${ }^{76}$ The family had a history of political involvement before 1688 . This was seen particularly keenly in the elder (father to Thomas and Ambrose) Ambrose Rookwood's direct involvement in Bury St Edmunds in James II's attempt to pack parliament in 1687. Ambrose was tied up in negotiations surrounding suitable persons for particular roles, as shown in one of the many letters from Lord Dover to John Stafford (the new Mayor to Bury and Lord Dover's inside man). ${ }^{77}$ Whilst his potential to influence local politics undoubtedly would have changed with the Glorious Revolution, it is unlikely that Ambrose would have discarded an interest in what was happening politically on a local level, and neither would neighbours have necessarily forgotten his involvement. Such records of the Rookwoods' political activities suggest that they were implicated in local and national politics in ways that precisely matched the stereotype of dangerous and disloyal Catholics.

Hints of Catholic political activism align with the work of Glickman on the resilience of the Catholic community at home and abroad. His emphasis that it was a community 'shaped as much by the politics of the modern nation as its own spiritual priorities', has offered a considerable revision of the notion that Catholics were quietly loyal and politically detached in the seventeenth and eighteenth centuries. ${ }^{78}$ Equally, the evidence for the Rookwoods matches up with Baker's findings for Nicholas Blundell in Lancashire. Despite that fact that they were formally excluded from politics, Catholics found ways to engage with contemporary political debate, and their political culture was by no means solely defined by their religion. ${ }^{79}$ As with their overt religious behaviour, the Rookwoods' suspect politics did not appear to prevent them from getting along with their neighbours. The evidence of the Rookwood 
family's political activity not only supports the recent revision of the view of Catholics as politically uninterested; it re-emphasizes the argument here that the reasons commonly given for the ability of Catholics and Protestants to get along on the local level in the face of anti-Catholic stereotypes do not present a full explanation.

\section{III}

It is with this in mind that the surprising extent to which the Rookwoods interacted with their Protestant neighbours should be examined. Unsurprisingly given their long history in Stanningfield, the Rookwoods had a significant social and economic role within the local community. As Lords of the manor they made substantial contributions to the poor rates, employed a number of people both permanently and casually, and leased their land. ${ }^{80}$ This is all to be expected of a gentry family, Catholic or otherwise. Yet in the detail of these interactions it is clear that the Rookwoods were able to have more than a functional relationship with local Protestants.

Thomas Rookwood undoubtedly had an important economic position within the local community, and this made everyday interaction with Protestants commonplace. Despite being incomplete, Thomas Rookwood's ledger gives a clear sense of the financial transactions which followed the rhythm of the agricultural calendar. Payments for ploughing, planting, mowing, threshing, and milling of corn, oats, barley, and wheat are recorded throughout the ledger alongside other work for maintaining the land, such as ditching, hedging, and managing woodland. ${ }^{81}$ In addition to farm work, Thomas recorded payments for other essential repairs and services, such as saddles and shoes for horses, fencing, and masonry, as well as the wages of his household servants. As Table 1 demonstrates, the yearly cost of maintaining a large estate was substantial, and local labourers and tradespeople were the economic beneficiaries of this. ${ }^{\mathbf{8 2}}$ 


\begin{tabular}{|l|l|l|l|}
\hline & $\mathfrak{l}$ & S & d \\
\hline Farm work* & 48 & 0 & 6 \\
\hline Household servants & 22 & 13 & 6 \\
\hline Other services** & 49 & 12 & 9 \\
\hline Total & 120 & 6 & 9 \\
\hline
\end{tabular}

Table 1: Expenditure on services, 1709

Based on an analysis of all transactions for the year 1709 (o.d), selected because of the completeness of entries for that year. Comparison with the partial entries for other years suggests that this is representative.

*'Farm work' applies to tasks involved in the management of agricultural land and production of farm goods.

**'Other services' applies to specific tasks not directly related to management of the land e.g. blacksmith's work.

Crucially, although it is impossible to identify for certain the religion of all Thomas Rookwood's labourers, a number of his regular workers were baptized as Protestants. Of the five labourers used most frequently by Rookwood in 1709 (Nottly, Tailor, Evis, Plume, and Parker), Nottly, Plume, and Parker can be identified on baptismal registers as Protestant. ${ }^{83}$ Edmond Plume does, however, appear to have been converted later in life: although he is recorded by Rookwood as a collector of land tax in April 1715 and does not appear on the list of papists for 1717 , he was registered in the 1725 returns of papists for Suffolk. ${ }^{84}$ Nevertheless, conversion does not appear widespread amongst Rookwood's associates, and whilst evidence of the religion of his house servants is scant two of the three of the servants mentioned in his will, Mary Sparrow (maid) and John Simpson (bailiff), can be positively identified as Protestant. ${ }^{85}$ Although frustratingly patchy, this evidence suggests that, as would be expected, Rookwood's associations with his economic subordinates were not religiously exclusive. That local Protestants were dependent on the Rookwood estate for income can only have helped the continued integration of the family within Stanningfield.

The contribution of the Rookwood estate to the local economy is further highlighted by records of the goods Rookwood purchased. Again taking the transactions Rookwood recorded in 1709 as a guide, it 
is evident from Table 2 that, as would be expected for a gentleman of means, he spent extensively on goods purchased in the local area. ${ }^{86}$ Any prolonged absence of the family would have been detrimental to local tradespeople. The family's butcher, for example, might have been expected to suffer considerably had the family been forced out of the area permanently. The mundane accounts of Thomas Rookwood highlight the extent to which the family made a substantial contribution the community's economic fabric. This may have had a particularly strong integrative effect in a period when economic credit, social behaviour, and moral norms were closely intertwined. As Craig Muldrew’s influential study has highlighted, the word 'credit' had no purely economic meaning in the early modern period, deriving instead from terms for trust and honour. The result was that community consisted of 'competing but interdependent households which had to trust one another'. ${ }^{87}$ The work of Laurence Fontaine has stressed, for instance, that mercantile activity was virtually impossible without trust, and that this meant ensuring that one's friends as well as one's trade contacts were reliable. ${ }^{88}$ Personal relationships were absolutely crucial in business and personal economic interaction, and had to be carefully guarded. Lost reputation was hard to recover. ${ }^{89}$ Explorations of the impact of this on economic interaction in the early modern period have been wide-ranging, from discussions of shopping to the establishment of the banking industry to understandings of the meaning of money. ${ }^{90}$ The Rookwoods' economic clout would have provided substantial motivation for local Protestants to ensure that they were considered by the family as creditable.

\begin{tabular}{|l|r|r|r|}
\hline & $£$ & S & d \\
\hline Clothing & 5 & 17 & 6 \\
\hline Wine and brandy & 13 & 17 & 12 \\
\hline Meat & 28 & 17 & 2 \\
\hline Other market goods & 78 & 1 & 6 \\
\hline For the horses & 34 & 18 & 2 \\
\hline
\end{tabular}




\begin{tabular}{|l|r|r|r|}
\hline Unidentified personal purchases & 15 & 16 & 11 \\
\hline Total & 177 & 9 & 3 \\
\hline
\end{tabular}

Table 2: Expenditure on goods, 1709

That this was indeed a factor in the acceptance of the family in the local area is demonstrated by examining the reasons behind the letter to Queen Anne written by Thomas Rookwood's neighbours in 1702, pleading for his return from exile. Of the eleven men who signed (Thomas Hanmer, Simonds D'Ewes, Robert Davers, John Poley, Thomas Robinson, Bartholomew Young, James Harvey, John Risby, George Wargrave, William Revett and Thomas Macro) a number would be expected to have been actively unsympathetic. Thomas Macro and Robert Davers appear to have laid aside political affiliations in their support for Rookwood. Both had been involved in the $1687 / 88$ attempt to pack parliament on the opposite side to Thomas's father Ambrose, who took Macro's place on Bury St Edmunds corporation in March 1688. It is unlikely that Macro would have forgotten this controversial case, and neither would Robert Davers, who shied away from representing the packed constituency on the grounds that he was doing work on his house. ${ }^{91}$ Both Davers and Thomas Hanmer were Members of Parliament, Davers for Bury (1689-1701 and 1703-1705) and Hanmer for Thetford (1701-1702 and 1705-1708) and Flintshire (1702-1705). They stood together, and won, for Suffolk in 1710. Both appear to have been classed by contemporaries as Hanoverian Tories, although Thomas Hanmer's background contains some intrigue. ${ }^{92}$ Whilst in his parliamentary action he was a firm supporter of Queen Anne, there is some evidence of his having contacted the Jacobite court in September 1712 and his loyalties may have been less clear-cut than his political career suggests. ${ }^{93}$ Neither man's biography suggests, however, a particular bent for supporting an errant Catholic gentleman. Other surprising supporters of Thomas Rookwood's return amongst the men who signed the letter included Bartholomew Young, the father of the famous Church of England clergyman and divine Arthur Young. ${ }^{94}$ William Revett, almost certainly of Bildeston Hall, also came from a Protestant family: his father was a clergyman. ${ }^{95}$ As a group, the individuals who signed the 
letter to Queen Anne held religious and political views which were far from a direct match to Rookwood's. Their unequivocal support for him thus demands illumination.

The economic roots of this action are highlighted by the reasons the men gave in their letter to Queen Anne for pleading for Rookwood's return from exile. The statement that 'his continuance in Exile will Fatally and inevitably involve him in great Debts, inextricable Law Suits, intirely ruine his Estate, and finally disable him from paying his just Debts, and consequently redound to many of your good subjects irrecoverable Loss and Detriment' is unambiguous in its implication. ${ }^{96}$ The authors of the letter were concerned about the financial impact of the Rookwoods' continuing absence. It is unclear what precisely his 'great Debts' would be, and to whom he owed them. However, Thomas Hanmer and Robert Davers do appear to have had a stake in the Rookwood estate. In a manoeuvre commonly used by Catholics in this period to protect their land, Thomas Rookwood appears to have conveyed his manors to Thomas Hanmer and Robert Davers in September $1697 .{ }^{97}$ Land conveyed by double trust was not registered as part of a Catholic estate, and was therefore free from the threat of double taxation and confiscation. ${ }^{98}$ Hanmer and Davers thus appear to have done Rookwood a great favour in holding his land in trust, but as a result may have had a vested interest in the fortunes of his estate. This goes some way to explaining why these two men, at least, were so eager to secure Rookwood's return from exile.

This does not, however, allow us to reduce the apparent acceptance of the Rookwoods within their local community to a matter of economic necessity. Thomas Hanmer and Robert Davers were only implicated in the Rookwood estate in the first place because they had sufficient confidence in his integrity to become trustees for his estate. The legal principle of trust was taken extremely seriously, and had a strong influence over the way in which disputes were settled in Chancery and under common law. ${ }^{99}$ Undertaking a trusteeship was therefore not to be done lightly. It is here that the striking social integration of the Rookwoods within their community may become important. The regular social and economic interaction of Thomas with local Protestants, including clergymen, implies that the religious divide was frequently crossed in Stanningfield beyond economic matters. Entries in Rookwood's ledger suggest that he socialized with the local parson, recording suppers at Parson Harvey's house (presumably Francis 
Harvey, rector of Lawshall) on 22 November 1715 and again on 10 February $1716 .{ }^{100}$ There are indications elsewhere that dining with Anglican clergymen was not unusual for Rookwood. In giving evidence in January 1714 regarding a dispute between one of Parson Rushbrook of Stanningfield's tenants and Thomas Rookwood over the cutting down of timber, Robert Davers indicated that social meetings between Rookwood and the local clergyman were not uncommon, mentioning a dinner at which this issue had been discussed. ${ }^{101}$ Crucially, the dinner took place inside the Catholic space of Coldham Hall, complete with its Catholic chapel and hanging religious images. ${ }^{102}$ The fact that both Robert Davers and the Protestant parson were friendly enough to give and receive dinner invitations from Rookwood indicates that there was an interconfessional sociability in Stanningfield that went beyond matters of economic necessity.

The broader gentlemanly conduct of Rookwood may have had further importance in securing their social position within the community. As Keith Wrightson's important work on the structure of early modern English society demonstrated, neighbourliness, which for the gentry tended to encompass members of the wider county as well as the parish, was built around 'a mutual recognition of reciprocal obligations of a practical kind'. ${ }^{103}$ That the eleven county notables who wrote to Queen Anne on Rookwood's behalf regarded him as their 'neighbour' is thus significant. The terms in which individuals described their relationships with one another were loaded with meaning during this period and attention to contemporary language can therefore give significant insight into early modern sociability. ${ }^{104} \mathrm{In}$ specifying that Rookwood was their neighbour, the individuals concerned implied that their action existed within a wider framework of neighbourly obligation between themselves and Rookwood. For Wrightson, such neighbourly bonds between gentry were formed by hunting, dining and other forms of sociability, and joint service in county administration. ${ }^{105}$ Rookwood's religion officially excluded him from the latter, but his ledger implies that he engaged in the former in good measure. Leo Gooch's work on northern Catholic gentry in the eighteenth century emphasizes the leisurely, sociable and scholarly conduct Catholic gentry in this period as a reminder that Catholics did not simply sit in their properties gathering dust. ${ }^{106}$ As well as taking his daughter to fairs, and dining with clergy and Robert Davers, Thomas had an 
interest in horse-breeding and hunting, and this led him to associate with other local Protestant gentlemen. A ledger entry for May 251712 notes 'My balle forrille mare take thee Lord Harvyes hors'. ${ }^{107}$ Lord Hervey was an influential man as Member of Parliament for Bury St Edmunds and Deputy Lieutenant for Suffolk, as well as a keen trainer and breeder of horses, his interest in which appears to have encouraged his association with Rookwood. ${ }^{108}$ Clearly whilst the interbreeding of Catholics and Protestants was frowned upon, this discrimination did not stretch to their horses. Expenses for hunting are often mentioned in the ledger, and come up particularly frequently in 1715 , when he appears to be consistently 'more out of pockett hunting'. ${ }^{109}$ In the same year he was also involved in other merriment, making an entry in January of that year 'for the dancing roome the $2^{\text {nd }}$ paymente'. ${ }^{110}$

Despite his Catholicism, Thomas Rookwood does not appear to have lived a stunted social life, and sporting associations with other local gentlemen were no doubt helpful to social integration beyond religious boundaries. ${ }^{111}$ This, in turn, may have encouraged the actions of Hanmer and Davers in acting as trustees for his estate. As Felicity Heal's extensive work on hospitality has shown, a reputation for being a good lord and an open household was important for a gentleman's overall reputation in their locality. ${ }^{112}$ This was linked to the importance of manners. Anna Bryson has highlighted just how central the idea of the "civil gentleman" was to social distinction in this period. It was thus crucial for an individual to reinforce a civil reputation by continuous contact with civil society. ${ }^{113}$ Rookwood's sociability was thus doubtless important in his being regarded as a 'neighbour' by other men of equal status in local society. ${ }^{114}$

The Rookwoods' relationships with their social inferiors may also have been important in solidifying their integration into their local community. The expectation of paternalistic action on the part of the landlord continued to be important in shaping social relations between subordinates and elites in this period. ${ }^{115}$ The dispensation of patronage was one way in which gentry could reinforce and demonstrate their status, and this may have been particularly significant for Catholic gentlemen who were excluded from exerting authority in office by virtue of their religion. ${ }^{116}$ Again, Thomas Rookwood's ledger suggests that he played his role well. Not only was he willing to grant advance payments to labourers, but he also demonstrated his generosity through giving a largess to his workmen. ${ }^{117}$ Such action 
was not only an investment in the goodwill of his labourers; it secured more firmly their interest in and dependence on him as a benevolent patron. ${ }^{118}$

The charitable activities of the family would have secured further their status as patrons of their local community. Heal's work has shown how the indiscriminate charity and hospitality of Catholics often gained them a reputation for benevolence which worked to their advantage when they ran into difficulties. ${ }^{119}$ In addition to his ordinary duties of paying for the overseers seals, Thomas's ledger records frequent charitable gifts, which he distributed at irregular intervals throughout the year. ${ }^{120}$ Meanwhile his will states his desire to ensure that after his death a gift would be given 'yearly at Christmas to the poore

of the Parish of Stanningfield the life and the same Dole I have usually given them in my life time'. ${ }^{121}$ His daughter Elizabeth also mentions frequent casual donations to the poor in the ledger after her father's death. Such generosity may have encouraged Thomas's Protestant neighbours to see him in a favourable light in a period when a reputation for honesty and charity was an important determinant in economic and social relations. ${ }^{122}$

The sociability and the economic importance of the Rookwoods therefore appear to have fed into each other to secure the necessity of the family within their locality despite their militantly Catholic stance. The economic power of the estate meant that many in the community relied on its survival for their livelihoods. Equally, evidence of Thomas Rookwood's social relationships suggests that sociability with local Protestant elites and patronage relationships with his social inferiors may have been important in securing his place within the network of relationships that made up local society.

\section{IV}

If contemporaries had searched for a live example of a Catholic family to support their anti-Catholic rhetoric, the Rookwoods would have been very suitable candidates. Not only could they be seen as idolatrous worshippers who engaged with Catholic and Protestant religious debates, but they were also 
priests, nuns and monks, figures heavily involved in maintaining the Catholic religion at home and abroad, ready for its return to dominance. Perhaps most importantly, they were loyal not only to a foreign Prince in the form of the Pope, but also to the exiled Stuart crown closely associated with popery and arbitrary government. This political danger was expressed in physical intention against the body of the monarch. In short, it would not have been unreasonable to see the Rookwoods as king-killing Jesuits who had little regard for the law and ultimately wished to overthrow the crown and impose foreign rule. The ability of Protestants in Stanningfield to get along with the Rookwood family could hardly have been based on a suspension of understandings of Catholics as religiously and politically threatening to Church and State.

Where does this leave us? It is certainly impossible to apply the image of Catholic quietude and compromise on a local level to the Rookwoods in Stanningfield. Instead we must look to the motives of Protestants in overlooking the offences of their Catholic neighbours. It was in the interests of those in authority to encourage anti-Catholic rhetoric and a strong Protestant identity. Values of loyalty to Church and monarch were essential safeguards of the stability of government and the life of the King or Queen. ${ }^{123}$ Yet the practical application of such animosity towards Catholics would not necessarily have been profitable to Protestants on a local level. Far from protecting the stability of society, had the Protestants of Stanningfield launched an anti-Catholic attack on the Rookwoods they would have caused a rupture in the social and economic functions of the community. The plea for Thomas Rookwood's return written by his neighbours in their letter of 1702 to Queen Anne makes this clear. His continued absence would have caused economic grief to his neighbours, both those who relied on his purchase of their services and those who, through his gentlemanly sociability with them, had become implicated in the fortunes of his estate. This was regardless of the fact that the Rookwoods were evidently an ardently Catholic and politically dangerous family. Thus at a time when the family was most vulnerable to anti-Catholic prejudice and exclusion from the neighbourhood, their return was regarded as a necessity. The action of these county elites in defending Rookwood has interesting implications for understanding the relationship between the central and local government in this period. The reluctance of local individuals to see their neighbour 
subjected to the full force of the state's law against Catholics reinforces the extent to which the state's power was mediated by local interests. This does not imply that the elite of Suffolk formed a closed "county community" in opposition to the concerns of the state, but rather stresses how neighbourly relationship were important in shaping the way in which powerful local individuals negotiated political and legal realities. ${ }^{124}$

In the Rookwoods' locality it was not any attempt by the family to distance themselves from the characteristics associated with anti-Catholic stereotypes that was the deciding factor in maintaining relative peace between Catholics and Protestants. The Rookwoods were tied into the Stanningfield community in three crucial ways. Firstly, they were long established there. They had a dominating physical presence through their property and ancestral presence in the very heart of the buildings of the Protestant church. ${ }^{125}$ This alone seems hardly sufficient to have prevented persecution for their religion. The removal of figures of authority at even the highest levels of power was not an impossibility within English society, as the events of 1649 and 1688 had shown. Rather, it is worth considering the Rookwood family's position in terms of their economic relationships with the rest of the community. Greater attention to the importance of trust and credit may provide further explanation for why Catholics and Protestants were able to get along even in the face of a strikingly militant Catholicism. Credit was an important guarantee in economic interactions, and an individual with a poor reputation would be met with deep distrust. ${ }^{126}$ As we have seen, the Rookwoods had significant economic power within Stanningfield and the surrounding area: they owned land producing plentiful resources; they had tenants who might need to rely on the goodwill of the family if they were unable to pay their rent on time; they needed to employ people for repairs and the upkeep of the house; they gave regularly to charity, both through the poor rates and casually; they purchased food and drink locally. Furthermore, and perhaps most crucially, they developed a strong enough relationship with local men of influence who became trustees of Rookwood land, and therefore had interests in it. Attempts by local Protestants to challenge the Rookwoods' Catholicism would therefore have presented significant risk of undermining the economic fabric of the community. 
Friendly relationships between the Rookwoods and their Protestant neighbours were a necessary part of economic and social life. Haydon emphasizes the extent to which anti-Catholicism could perform the function of social bonding against a common enemy, but such an effect would be diluted if persecution of such an 'enemy' would stifle economic well-being. ${ }^{127}$ The existence of an economic incentive for Protestants to get along with their Catholic neighbours may have been a powerful influence over the 'moral dilemmas' of everyday existence faced by Protestants in Stanningfield. ${ }^{128}$ Crucially, however, the apparently pragmatic response of Protestants was not matched by the compromise of Catholics in this case.

This is not to suggest that local Protestants separated social credit and its economic implications from religious imperatives. The centrality of morality to economic culture beyond the realm of credit relations has been demonstrated convincingly by Brodie Waddell, who argues that any notion of a dichotomy between "moral" and "market" mentality should be replaced by an understanding of economic action as informed by 'a blend of innumerable different cultural streams - including ideals based on theology, family, and community'. ${ }^{129}$ Notions of social and economic obligation had some basis in contemporary theories of toleration and what it meant to be a good Christian. Augustinian views on the importance of coercion in bringing the misled to the truth as an act of Christian charity still prevailed in some sermons and writings, such as those of Richard Perrinchief and Francis Fullwood. ${ }^{130}$ Yet others put forward rather gentler definitions of what it meant to be charitable. In a 1696 sermon the vicar of Orpington in Kent, Thomas Watts, defined a 'truly Charitable Person' as someone who 'owes no Man anything but love... and is in Charity with his most inveterate Foes, as he can't be an Enemy to any'. His later reflection that in 'this unhappy Kingdom...the pretended Love of Christ...has set Father against Son, Brother against Brother' highlights his desire that Christian charity should be a force for reconciliation. ${ }^{131}$ Such a need for gentle treatment of enemies is again seen in an anonymous prayer printed in 1690, which prescribes that clergy 'ought not to strive, but be gentle unto all men...apt to teach, patient, in meekness instructing those who oppose themselves: That they may become Examples unto their flocks'. ${ }^{132}$ The point here is clear - those with opposing ideas should act kindly and reconcile rather than alienate. As 
Alexandra Walsham has highlighted, tolerance within local communities was in part based on the idea of 'good neighbourhood' as influential in Christian thinking as well as a genuine belief in the idea of toleration. ${ }^{133}$ State policy and popular polemic encouraged persecution but on a local level the accumulation of social credit, so essential within the economy of obligation, rested to some extent on the pursuit of Christian charity. Thus whilst communities were encouraged through acts of parliament to persecute 'bloody Papists' such as the Rookwoods, economic practicality combined inextricably with the need to be a good Christian and neighbour appears in Stanningfield to have drawn individuals towards a much friendlier approach to their Catholic neighbours.

Explanations based around "getting along" remain powerful; interconfessional relations were undoubtedly a matter of give and take on a personal level and within the wider community. The agenda for compromise, however, was not necessarily set by the established religious majority. As the example of the Rookwoods demonstrates, uncompromising Catholicism was compatible with peaceful coexistence in post-revolutionary England. When faced with the entangled series of moral dilemmas that everyday life presented in Stanningfield, the relationship between religious practice, political ideology, and local compromise is surprising. Militant Catholicism was met by Protestant accommodation, and not, as might be expected, the reverse. Peaceful coexistence in post-revolutionary England relied on pragmatic compromise from one or all confessions concerned, but we should not assume that the onus for this was always on the minority faith. For the Rookwoods in Stanningfield, the interplay between faith, politics, and social and economic necessity created the specific conditions in which their militant Catholicism could survive. Their example suggests that before we can understand what the compromises were that allowed communities to "get along" we must first unpick the complex impulses behind the local balance of power that determined who it was that had to compromise.

St John's College, Cambridge, CB21TP clmb3@cam.ac.uk

* I am very grateful to Alexandra Walsham for her encouragement and reading of drafts, and to Harriet Lyon 
for helpful suggestions and good humour. I would also like to thank Phil Withington and the anonymous referees of Historical Journal for their comments on earlier drafts. This article draws on research undertaken for my BA thesis at Murray Edwards College, Cambridge, and a paper subsequently delivered at the Catholic Record Society Conference in July 2015; in both instances I was grateful to Francis Young for sharing his expert knowledge on the Rookwoods.

${ }^{1}$ Letter of neighbours and acquaintances of Thomas Rookwood to Queen Anne, 1702, Cambridge, Cambridge University Library (CUL), MS Hengrave 76/2/21.

${ }^{2}$ Alexandra Walsham, Charitable hatred: Tolerance and intolerance in England (Manchester, 2006), p. 5.

${ }^{3}$ Willem Frijhoff, Embodied belief: Ten essays on religious culture in Dutch history (Hilversum, 2002), p. 40.

${ }^{4}$ Benjamin J. Kaplan, Divided by faith: Religious conflict and the practice of toleration in early modern Europe (Cambridge, MA, 2007), p. 10.

${ }^{5}$ William Sheils, “"Getting on" and "getting along” in parish and town: Catholics and their neighbours in England' in B. Kaplan, B. Moore, H. Van Nierop, and J. Pollman, eds., Catholic communities in Protestant states. Britain and the Netherlands c. 1570-1720 (Manchester, 2009), p. 68.

${ }^{6}$ Nadine Lewycky and Adam Morton, 'Introduction' in Lewycky and Morton, eds., Getting along? Religious identities and confessional relations in early modern England-essays in honour of Professor W. J. Sheils (Farnham, 2012), p. 9.

${ }^{7}$ Colin Haydon, Anti-Catholicism in eighteenth-century England c. 1714-80 (Manchester and New York, NY, 1993), p. 253.

${ }^{8}$ Ibid, p. 13.

${ }^{9}$ Gregory Hanlon, Confession and community in seventeenth-century France: Catholic and Protestant coexistence in Aquitaine (Pennsylvania, PA, 1993), p. 9.

${ }^{10}$ Malcolm Wanklyn, 'Catholics in the village community: Madeley, Shropshire, 1630-1770' in Marie B. Rowlands, ed., English Catholics of parish and town, 1558-1778 (London, 1999), p. 225.

${ }^{11}$ William Sheils, “"Getting on" and "getting along”, pp. 67-83.

${ }^{12}$ John Bossy, 'English Catholics after 1688' in Peter Ole Grell, Jonathan I. Israel and Nicholas Tyacke, 
eds., From persecution to toleration: The Glorious Revolution and religion in England (Oxford, 1991), p. 381. 381.

${ }^{13}$ W. J. Sheils, 'Catholics and their neighbours in a rural community: Egton chapelry, 1590-1780', Northern History, 34 (Jan., 1998), pp. 109-133, at pp. 126, 130.

${ }^{14}$ Lewycky and Morton, 'Introduction', p. 11.

${ }^{15}$ Haydon, Anti-Catholicism, p. 11.

${ }^{16}$ Kaplan, Divided by faith, p. 265.

${ }^{17}$ See especially Gabriel Glickman, The English Catholic community, 1688-1745 (Woodbridge, 2009); Geoff Baker, Reading and politics in early modern England: The mental world of a seventeenth-century Catholic gentleman (Manchester and New York, NY, 2010).

18 'Vertissimas Prosapia Rookwodarum de Stannigefielde', 1619, CUL, MS Hengrave 76/1.

${ }^{19}$ Letter from Robert Rookwood to His Majesty's Attorney General, 1636, Bury St Edmunds, County Record Office (CRO Bury), 326/52.

${ }^{20}$ Proceedings of the commissioners of forfeited estates under statutes $1 \& 4$ George I, Kew Gardens, The National Archives (TNA), FEC 2/68, p. 163.

${ }^{21}$ Suffolk Church notes, vol. 1, n.d., CUL, MS Hengrave 22/1.

${ }^{22}$ Peter Marshall, 'Confessionalisation and community in the burial of English Catholics, c. 1570-1700' in Lewycky and Morton, eds., Getting Along? p. 62.

23 'Rookwood family tree', Who were the nuns? 〈http://wwtn.history.qmul.ac.uk/ftrees/Rookwood.pdf>.

${ }^{24}$ Anthony Kenny, ed., The Responsa Scholarum of the English College, Rome, Part Two, 1622-1685

(London, 1963); Dominic Aidan Bellenger, ed., English and Welsh Priests 1558-1880 (Bath, 1984); Geoffrey Holt, St Omers and Bruges Colleges, 1593-1773: A biographical dictionary (London, 1979); Who were the nuns? $\langle$ http://wwtn.history.qmul.ac.uk/>.

${ }^{25}$ Coldham Hall ledger, c. 1695-1751, CUL, MS Hengrave 76/3.

${ }^{26}$ A volume of the Rookwood family papers edited by Francis Young is due for publication by the Suffolk Record Society in 2016. 
${ }^{27}$ Haydon, Anti-Catholicism, passim; John Bossy, The English Catholic community, 1570-1850 (London, 1975), p.5; Leo Gooch, "“The religion for a gentleman": The northern Catholic gentry in the eighteenth Recusant History, 23 (1997), pp. 453-568, at pp. 544, 565.

${ }^{28}$ Jan Albers "'Papist traitors" and "Presbyterian rogues": religious identities in eighteenth-century Lancashire' in John Walsh, Colin Haydon, and Stephen Taylor, eds., The Church of England, c. 1689-c.1833: From toleration to tractarianism (Cambridge, 1993), p. 324.

${ }^{29}$ Quoted in Haydon, Anti-Catholicism, p.22.

${ }^{30}$ Isaac Bickerstaff (alias Jonathan Swift), The Popish Courant (London, 1714), p.1.

${ }^{31}$ Peter Lake, 'Anti-popery: the structure of a prejudice' in R. Cust and A. Hughes, eds., Conflict in early Stuart England (New York, NY, 1989), p. 76.

${ }^{32}$ Haydon, Anti-Catholicism, pp. 32ff, 38ff.

${ }^{33}$ Coldham Inventory, CUL, MS Hengrave 77/2, fos. 8v, 9r, 10v.

${ }^{34}$ Clare Haynes, 'The Politics of religious imagery in the late seventeenth century' in Jason McElligot, ed., Fear, exclusion and revolution: Roger Morrice and Britain in the 1680s (Aldershot, 2006), p.51.

${ }^{35}$ CUL, MSS Hengrave 77/2, fos. 28v-53r.

${ }^{36}$ Ibid, fo. $47 \mathrm{r}$.

${ }^{37}$ For an example of how records of reading habits can be revealing of the political and religious mindsets of an individual, see Baker, Reading and politics in early modern England. Further analysis of the Rookwoods' collection in this vein may prove fruitful.

${ }^{38}$ For explorations of the significance of a distinction between public and nominally private worship in early modern Europe, see Benjamin Kaplan, 'Fictions of privacy: House chapels and the spatial accommodation of religious dissent in early modern Europe', The American Historical Review, 107 (October 2002), pp. 1031-1064.

${ }^{39}$ CUL, MS Hengrave 76/3, fos. 106r-107v; College of Holy Apostles District Acts, 1667-1844, London, Archives of the British Province of the Society of Jesus (BPSJ), fos. 21-2, 24, 26-8, 30-1, 33.

${ }^{40}$ BPSJ: BA/5 - Coldham - notes by Fr. Legros S.J. And correspondence concerning the mission, p.5.

${ }^{41}$ Ibid, p. 6; Thompson Cooper, G. Bradley, 'Garnett, Thomas [St Thomas Garnett] (1575-1608)', 
ODNB, <http://www.oxforddnb.com/view/article/10394>.

${ }^{42}$ Sheils, 'Catholics and their neighbours in a rural community', p. 130.

${ }^{43}$ G. Lyon Turner, and ed., Original records of early nonconformity under persecution and indulgence (3 vols., London, 1911) i, p.103; Many thanks to Mr Matti Watton at Lambeth Palace Library for confirming the transcribed spelling in the original manuscript.

44 'Rookwood family tree', Who were the nuns? 〈http://wwtn.history.qmul.ac.uk/ftrees/Rookwood.pdf〉.

${ }^{45}$ CUL, MS Hengrave 76/3, fos. 106r-107v.

${ }^{46}$ Ibid, fo. 95 r.

${ }^{47}$ Ibid, fos. $93 \mathrm{v}, 95 \mathrm{v}$.

48 'Rookwood family tree', Who were the nuns?.

${ }^{49}$ William III, 1698-9: An Act for the further preventing the growth of popery. [Chapter IV. Rot. Parl. 11 Gul. III. p. 2. n. 2.]', Statutes of the Realm, vol. 7, 1695-1701 (1820), pp. 586-587, <http://www.britishhistory.ac.uk/report.aspx? compid=46963>.

${ }^{50}$ Claire Walker, Gender and politics in early modern Europe (Hampshire and New York, NY, 2003); Claire Walker, 'Prayer, patronage, and political conspiracy: English nuns and the Restoration', Historical Journal, 43 (Mar., 2000), pp. 1-23.

${ }^{51}$ Walker, Gender and politics, p. 116.

${ }^{52}$ See particularly Geoffrey Scott, 'The Throckmortons at home and abroad, 1680-1800' in Peter Marshall and Geoffrey Scott, eds., Catholic gentry in English society: The Throckmortons of Coughton from Reformation to Emancipation (Farnham, 2009), pp. 180-7. For the development of Catholic networks in Suffolk in late Tudor period, see Joy Rowe, “"The lopped tree”: the re-formation of the Suffolk Catholic community' in Nicholas Tyacke, ed., England's long Reformation 1500-1800 (London, 1998), pp. 175-8.

${ }^{53}$ Haydon, Anti-Catholicism, pp. 32-5, 38-40.

${ }^{54}$ Gilbert Burnet, 'A sermon concerning popery; preached at the end of King Charles's Reign', in Burnet, Some sermons preach'd on several occasions; and an essay towards a new book of homilies, in seven sermons, Prepar'd at the desire of Archbishop Tillotson, and some other bishops (London, 1713), p. 110.

${ }^{55}$ Martin Greig, 'Burnet, Gilbert (1643-1715)', ODNB <http://www.oxforddnb.com/view/article/4061〉. 
${ }^{56}$ William Crookshank, Popish cruelty represented: In a sermon occasioned by the present rebellion in Scotland; preach'd September 22d, 1745, to the Scots Church in Swallowstreet, Westminster (London: 1745), p. 1.

${ }^{57}$ Andrew Thompson, 'Popery, politics, and private judgement in early Hanoverian Britain', The Historical Journal, 45 (June, 2002), pp. 333-356, at pp. 342-3, 336, 338.

${ }^{58}$ Bob Harris, Politics and the nation: Britain in the mid-eighteenth century (New York, NY, 2002), p. 6.

${ }^{59}$ Paul Chapman, 'Jacobite political argument in England, 1714-1766' (PhD thesis, Cambridge, 1985), p.4.

${ }^{60}$ Neil Guthrie, Material culture of the Jacobites (Cambridge, 2013) p. 2; Murray Pittock, 'Treacherous objects: towards a theory of Jacobite material culture', Journal for Eighteenth-Century Studies, 34 (Mar., 2011), pp. 39-63, at pp. 45-6. See also Murray Pittock, Material culture and sedition 1688-1760: Treacherous objects, secret places (Basingstoke, 2013).

${ }^{61}$ Daniel Szechi, The Jacobites in Britain and Europe, 1688-1788 (Manchester and New York, NY, 1994), p. 12.

${ }^{62}$ Glickman, The English Catholic community, pp. 191, 217.

${ }^{63}$ Paul S. Fritz, The English minister and Jacobitism between the rebellions of 1715 and 1745 (Toronto, ON, and Buffalo, NY, 1975), pp. 99-100; Eveline Cruickshanks, 'Walpole's tax on Catholics', Recusant History, 28 (May 2006), pp. 95-102, at p. 101.

${ }^{64}$ Eveline Cruickshanks, 'The Political management of Sir Robert Walpole, 1720-42' in Jeremy Black, ed., Britain in the age of Walpole (Basingstoke, 1984), pp. 28-9.

${ }^{65}$ William Cobbett, Cobbett's parliamentary history of England: From the Norman Conquest, in 1066, to the year 1803 (36 vols, London, 1811) viii, p. 52.

66 'Charles II, 1678: (Stat. 2.) An Act for the more effectuall preserving the Kings Person and Government by disableing Papists from sitting in either House of Parlyament.' in John Raithby, ed., Statutes of the realm (9 vols., London: 1819) v, pp. 894-896, <https://www.british-history.ac.uk/statutes-realm/vol5/pp894-896>.

67 'William and Mary, 1688: An act for exempting their Majestyes Protestant subjects dissenting from the Church of England from the penalties of certaine lawes. [Chapter XVIII. Rot. Parl. pt. 5. nu. 15.]' in John 
Raithby ed., Statutes of the realm, vi, pp. 74-6, 〈http://www.british-history.ac.uk/statutes-realm/vol6/pp74-76>. 76).

${ }^{68}$ 'Charles II, 1678: (Stat. 2.) An Act for the more effectuall preserving the Kings person'; 'House of Lords Journal volume 20: 26 June 1716', in Journal of the House of Lords, 1714-1717 (243 vols, London, n.d.) xx, pp. 395-7, <http://www.british-history.ac.uk/lords-jrnl/vol20/pp395-397>.

${ }^{69}$ 'William III, 1697-8: An act against corresponding with the late King James and his adherents. [Chapter I. Rot. Parl. 9 Gul. III.p. 1.n.1]', in Raithby, ed., Statutes of the realm, vii, pp. 295-296, < http://www.britishhistory.ac.uk/statutes-realm/vol7/pp295-296>; 'William III, 1698-9: An act for the further preventing the growth of popery [Chapter IV. Rot. Parl. 11 Gul. III. p. 2. n. 2.]', in Raithby, ed., Statutes of the realm, vii, pp. 586-7, $<$ http://www.british-history.ac.uk/statutes-realm/vol7/pp586-587>.

${ }^{70}$ Anon., The arraignment, tryal, and condemnation of Ambrose Rookwood, for the horrid and execrable conspiracy to assassinate his sacred majesty King William (London, 1696), p. 2. See also Anon., True copies of the papers which Brigadier Rookwood, and Major Lowick, delivered to the sheriffs of London and Middlesex, at Tyburn, April 29. 1696 (London, 1696); Anon., An account of the execution of Brigadier Rookwood, Major Lowick, and Mr. Cranburn (London, 1696); Anon., A true account of the dying behaviour of Ambrose Rookwood, Charles Cranburne, and Major Lowick (London, 1696).

${ }^{71}$ Thomas Percival, The Rye-house travestie, or, a true account and declaration of the horrid and execrable conspiracy against His Majesty King William and the government (London, 1696), p. 2.

${ }^{72}$ R. Blackmore, A true and impartial history of the conspiracy against the person and government of King William III (London: 1723), pp. 64-65.

${ }^{73}$ TNA, C 213/264/22. Two others in Stanningfield refused the oath: Thomas Burlton, gent, and Robert Flower.

${ }^{74}$ CUL, MSS Hengrave 76/2/21.

${ }^{75}$ Returns of Papists, Suffolk, TNA, E174/1/27, 23 September 1725.

${ }^{76}$ John Bossy, 'English Catholics after 1688', p. 381.

${ }^{77}$ Pat. E. Murrell, 'Bury St. Edmunds and the campaign to pack Parliament, 1687-8', Historical Research, 54 (Nov., 1981), pp. 188-206, at p. 190; Lord Dover to John Stafford, Bury CRO, E2/41/5, fo. 51r. 
${ }^{78}$ Glickman, The English Catholic community 1688-1745, p.7.

${ }^{79}$ Baker, Reading and politics.

${ }^{80}$ CUL, MS Hengrave 76/3, particularly fos. 5r-14r.

${ }^{81}$ CUL, MS Hengrave 76/3, passim.

${ }^{82}$ Ibid, fos. $13 \mathrm{v}-22 \mathrm{v}, 28 \mathrm{r}-33 \mathrm{r}, 92 \mathrm{v}$.

${ }^{83}$ Stanningfield Parish, registers of baptisms, CRO Bury, FL626/4/1/1, 1561-1702.

${ }^{84}$ CUL, MS Hengrave 76/3, fo. 3v; Popish recusants: Abstracts of estates, Suffolk, TNA, FEC 1/1275, 5 Jan 1717; Returns of Papists, Suffolk, TNA, E174/1/27, 23 September 1725.

${ }^{85}$ Will of Thomas Rookwood, TNA, Prob 11/614, 1727; CRO Bury, FL626/4/1/1.

${ }^{86}$ CUL, MS Hengrave 76/3, fos. 13r-17r, 30v-31v.

${ }^{87}$ Craig Muldrew, The economy of obligation: The culture of credit and social relations in early modern England (Basingstoke, 1998), pp. 3, 4.

${ }^{88}$ Laurence Fontaine, The moral economy: Poverty, credit, and trust in early modern Europe

(Cambridge, 2014), p. 277.

${ }^{89}$ Craig Muldrew, 'Interpreting the market: the ethics of credit and community relations in early modern England', Social History, 18 (May, 1993), pp. 163-183, at p. 174; Peter Mathias, 'Risk, credit and kinship in early modern enterprise', in John J. McCusker and Kenneth Morgan, eds., The early modern Atlantic economy (Cambridge, 2000), pp. 28-9.

${ }^{90}$ Including Jon Stobart, Sugar and spice: Grocers and groceries in provincial England, 1650-1830 (Oxford, 2013); Larry Neal and Stephen Quinn, 'Networks of information, markets, and institutions in the rise of London as a financial centre, 1660-1720', Financial History Review, 8 (April, 2001), pp. 7-26; Deborah Valenze, The social life of money in the English past (Cambridge, 2006).

${ }^{91}$ Murrell, 'Bury St. Edmunds and the campaign to pack Parliament', pp. 204, 200, 203.

${ }^{92}$ Eveline Cruickshanks, Stuart Handley, and D. W. Hayton, eds., The History of Parliament: the House of Commons 1690-1715 (Online edn, 2002), <http://www.historyofparliamentonline.org/volume/16901715/member/hanmer-thomas-ii-1677-1746>, 〈http://www.historyofparliamentonline.org/volume/16901715/member/davers-sir-robert-1653-1722>. 
${ }^{93}$ D. W. Hayton, 'Hanmer, Sir Thomas, fourth baronet (1677-1746)', ODNB,

$\langle$ http://www.oxforddnb.com/view/article/12205〉.

${ }^{94}$ E. I. Carlyle, 'Young, Arthur (1693-1759)', Rev. B. W. Young, ODNB, 〈http://www.oxforddnb.com/view/article/30255〉.

${ }^{95}$ Frederic Salmon Growse, Materials for a history of the parish of Bildeston, in the county of Suffolk (n.p., 1892), p. 57; H. McKeon, An inquiry into to birth-place, parentage, life and writings, of the Reverend William Gurnall, M. A. (Woodbridge, 1830), p. 131.

${ }^{96}$ CUL, MS Hengrave 76/2/21.

${ }^{97}$ Robert Robson, The attorney in eighteenth-century England (Cambridge, 1959), p.76, fn; Deed of recovery, CRO Bury, 449/4/19 (loose bundle), 24 May 1711.

${ }^{98}$ Nathaniel Pigott to Robert Throckmorton, Warwick, Warwickshire County Record Office (Warwick CRO), CR1998/Box65/folder2/7, 24 October 1704.

${ }^{99}$ N. G. Jones, 'Wills, trusts and trusting from the Statute of Uses to Lord Nottingham', Journal of Legal History, 31 (Dec., 2010), pp. 273-298, at pp. 290, 295.

${ }^{100}$ CUL, MS Hengrave, 76/3, fos. 11r, 10v; 'Harvey, Francis (1699-1732)', The Clergy Database, $\langle$ http://db.theclergydatabase.org.uk/jsp/persons/DisplayCcePerson.jsp?PersonID=125470〉.

${ }^{101}$ Babbage vs. Rookwood, TNA, E134/1Geo1/Hi17, 1714, fo. 2; 'Rushbrook, Robert', The Clergy Database, $<$ http://db.theclergydatabase.org.uk/jsp/persons/DisplayPerson.jsp?PersonID=127074〉 .

${ }^{102}$ CUL, MS Hengrave 77/2, fos. 8v, 9r, 10v.

${ }^{103}$ Keith Wrightson, English society, 1580-1680 (Abingdon, 2003), pp. 59, 64.

${ }^{104}$ Naomi Tadmor, Family and friends in eighteenth-century England (Cambridge, 2001), pp. 165, 205; Phil Withington, 'Company and sociability in early modern England', Social History, 32 (Aug., 2007), pp. 291-307, at pp. 296-7.

${ }^{105}$ Wrightson, English society, p. 49.

${ }^{106}$ Leo Gooch, '“The Religion for a gentleman'.

${ }^{107}$ CUL, MS Hengrave 76/3, fo. $6 v$. 
${ }^{108}$ Philip Carter, 'Hervey, John, first earl of Bristol (1665-1751)', ODNB,

<http://www.oxforddnb.com/view/article/13117>.

${ }^{109}$ CUL, MS Hengrave 76/3, fos. 10v-11r.

${ }^{110}$ Ibid, fo. 10v.

${ }^{111}$ Gooch, '“The Religion for a Gentleman”', p. 565.

${ }^{112}$ Felicity Heal, Hospitality in early modern England (Oxford, 1990), p. 13.

${ }^{113}$ Anna Bryson, From courtesy to civility: Changing codes of conduct in early modern England (Oxford, 1998), pp. 278, 282.

${ }^{114}$ This is an unfortunately gendered presentation of the dynamics of social relations in Stanningfield, determined by the paucity of evidence about the activities of female members of the family. Female sociability was important in regulating and creating moral norms in early modern England; we can only speculate what role the female Rookwoods may have played a crucial role in negotiating the family's local status. See for example Laura Gowing, Gender relations in early modern England (Abingdon, 2014), pp. 5166; Amanda Flather, Gender and space in early modern England (Woodbridge, 2007), pp. 94-134.

${ }^{115}$ Andy Wood, 'Deference, paternalism and popular memory in early modern England' in Steve Hindle, Alexandra Shepard and John Walter, eds., Remaking English society: Social relations and social change in early modern England (Woodbridge, 2013), pp. 239, 252.

${ }^{116}$ Steven Shapin, A social history of truth (Chicago, IL, 1994), pp. 49, 87; Susan Cogan, 'Reputation, credit and patronage: Throckmorton men and women, c. 1560-1620' in Peter Marshall and Geoffrey Scott, eds., Catholic gentry in English society, pp. 71, 85, 90-91.

${ }^{117}$ CUL, MS Hengrave 76/3, fos. 13v, 22r-v.

${ }^{118}$ Wrightson, English society, p. 69.

${ }^{119}$ Felicity Heal, Hospitality in early modern England (Oxford, 1990), pp. 97-8.

${ }^{120}$ CUL, MS Hengrave 76/3, particularly fos., 7v, 8r, 8v, 15v.

${ }^{121}$ Will of Thomas Rookwood, TNA, Prob 11/614, 1727.

${ }^{122}$ Muldrew, The economy of obligation, especially pp. 149ff.

${ }^{123}$ Colin Haydon, Anti-catholicism, pp. 43, 71ff. See also Colin Haydon, '“I love my King and my 
Country, but a Roman catholic I hate": anti-catholicism, xenophobia and national identity in eighteenth-century century England', in Claydon and McBride, eds., Protestantism and National Identity, pp. 53-74.

${ }^{124}$ Clive Holmes, 'The county community in Stuart historiography', Journal of British Studies, 19 (Spring, 1995), pp. 54-73, at p.73; Mark Goldie, 'The unacknowledged republic: officeholding in early modern England' in Tim Harris, ed., The politics of the excluded, c. 1500-1850 (Basingstoke, 2001), p. 166; Michael Braddick, 'State formation and social change in early modern England: a problem stated and approaches suggested', Social History, 16 (Jan., 1991), pp. 1-17, at p. 15.

${ }^{125}$ Suffolk Church notes, CUL, MS Hengrave 22/1, vol. 1, n. d.

${ }^{126}$ Muldrew, The economy of obligation, pp. 3-4, 7.

${ }^{127}$ Haydon, Anti-catholicism, p. 253.

${ }^{128}$ Lewycky and Morton, 'Introduction', p. 11.

${ }^{129}$ Brodie Waddell, God, duty and community in English economic life, 1660-1720 (Woodbridge, 2012), p. 229, passim.

${ }^{130}$ Mark Goldie, 'The theory of religious intolerance in Restoration England', in Grell, Israel and Tyacke, eds., From persecution to toleration, pp. 337-47.

${ }^{131}$ Thomas Watts, Universal Christian charity, as comprehending all true religion and happiness, demonstrated from scripture and reason in a sermon preach'd before the Right Hon. Lord Chief Justice Treby, at the assizes held at Maidstone in Kent (London, 1697), pp. 17ff.

${ }^{132}$ Anon., A prayer for charity, peace and unity, to be used in Lent (London, 1690), p.5.

${ }^{133}$ Walsham, Charitable hatred, pp. 272-3. 